\title{
Kajian Kualitas Air Sungai Meduri Pekalongan Akibat Pembuangan Limbah Cair Batik Berdasarkan Indikator Biologi
}

\section{Assessment Of Water Quality In Pekalongan Meduri River Due To Batik Waste Disposal Based On Biologycal Indicators}

\author{
Mahardhika Nur Permatasari $^{1}$, Heri Ariadi $^{1}$ *, Benny Diah Madusari ${ }^{1}$, Hayati Soeprapto $^{1}$ \\ ${ }^{1}$ Program Studi Budidaya Perairan, Fakultas Perikanan, Universitas Pekalongan, Jalan Sriwijaya No. 3 \\ Pekalongan, Jawa Tengah \\ *Corresponding author: ariadi_heri@yahoo.com
}

Submitted: 16 August 2021 Revised: 04 October 2021 Accepted: 06 October 2021 Publish: 30 October 2021

\section{Abstrak}

Sungai Meduri merupakan salah satu sungai di Kabupaten Pekalongan yang diindikasikan tercemar oleh limbah batik. Tujuan penelitian ini adalah mengetahui kualitas sungai ditinjau dari aspek fisika (suhu, kecerahan, TSS dan kedalaman), aspek kimia (DO, pH, BOD, $\mathrm{Cr}^{6+}$, Minyak dan Fenol) dan aspek biologi (plankton). Penelitian ini dilakukan pada bulan mei - juni 2015. Pengambilan sampel dilakukan sebanyak 3 kali dengan interval waktu 2 minggu. Komunitas plankton di Sungai Meduri terdiri dari kelas Barcillariophyceaea, Chlorophycea, Chyanophyceae, Rotatoria dan Entomostraca. Kelimpahan berkisar antara 1104 - 5393, Indeks keanekaragaman (H') sebesar 1,011-1,885. Indeks keseragaman (E') berkisar antara 0,564-0,978 dan indeks Dominasi berkisar antara 0,022-1,000.pada sungai Meduri tidak ada biota yang mendominasi. Kandungan Biological Oxygen Demand di perairan sungai ini melebihi baku mutu air kelas III yaitu >3 mg/L (PP RI No. 82 Tahun 2001). Disisi lain, nilai $\mathrm{Cr}^{6+}$ dan minyak masih berada dibawah baku mutu air kelas III yaitu $0,05 \mathrm{mg} / \mathrm{L}$ dan $1000 \mathrm{mg} / \mathrm{L}$. Sedangkan nilai fenol tertinggi terdapat pada stasiun 3 dan 4, masing masing sebesar 0,11mg/L dan 0,07 mg/L.

Kata Kunci : Sungai Meduri, Kualitas Air, Plankton, Pekalongan

\begin{abstract}
Meduri River is one of the rivers in Pekalongan Regency which is indicated to be polluted by batik waste. The purpose of this study was to determine the quality of the river in terms of physical aspects (temperature, brightness, TSS, and depth), chemical aspects (DO, pH, BOD, Cr6+, Oil, and Phenol), and biological aspects (plankton). This research was conducted in May - June 2015. Sampling was carried out 3 times with an interval of 2 weeks. The plankton community in the Meduri River consists of the classes Barcillariophyceaea, Chlorophyceae, Chyanophyceae, Rotatoria, and Entomostraca. Abundance ranged from 1104 - 5393, the diversity index $\left(\mathrm{H}^{\prime}\right)$ was 1.011-1.885. The uniformity index (E') ranges from 0.5640.978 and the dominance index ranges from $0.022-1,000$. There is no dominant biota in the Meduri river. The content of Biological Oxygen Demand in the waters of this river exceeds the class III water quality standard, which is $>3 \mathrm{mg} / \mathrm{L}$ (PP RI No. 82 of 2001). On the other hand, the value of $\mathrm{Cr6}^{+}$and oil is still below the class III water quality standards, namely $0.05 \mathrm{mg} / \mathrm{L}$ and $1000 \mathrm{mg} / \mathrm{L}$. Meanwhile, the highest phenol values were found at stations 3 and 4, respectively $0.11 \mathrm{mg} / \mathrm{L}$ and $0.07 \mathrm{mg} / \mathrm{L}$.

Keyword : Meduri River, Water Quality, Plankton, Pekalonga
\end{abstract}

\section{PENDAHULUAN}

Meningkatnya industri batik di Pekalongan selain memberikan dampak positif terhadap peningkatan pendapatan daerah tetapi juga memberikan dampak negatif berupa pencemaran lingkungan. Semakin pesatnya pertumbuhan industri batik berarti semakin banyak limbah yang dihasilkan. Polutan limbah batik akan sangat mempengaruhi kualitas air

di sekitar lokasi pencemaran (Eskani
dkk, 2005). Salah satu area lokasi
pembuangan limbah batik di Kota
Pekalongan berada di sungai Meduri.
Banyaknya zat pencemar yang ada di
dalam air limbah yang dibuang ke sungai
Meduri akan berpengaruh terhadap
kesuburan dan menganggu
keseimbangan ekosistem perairan.


Pencemaran dapat mengubah struktur dan mengurangi jumlah spesies dalam suatu komunitas (Astirin dkk, 2002). Limbah cair batik secara akumulatif dapat mempengaruhi sifat fisik dan kimia ekosistem sungai, sehingga salah satunya akan menurunkan indeks diversitas plankton dan kondisi kualitas air sungai (Indarsih, 2011). Plankton memiliki peranan penting sebagai produsen primer yang dapat melakukan proses fotosintesis dan menghasilkan karbohidrat serta oksigen pada ekosistem perairan (Nontji, 2005). Sedangkan kualitas air adalah parameter kritis yang sangat menentukan kondisi lingkungan perairan (Ariadi dkk, 2019).

Tingkat pencemaran suatu perairan termasuk sungai Meduri di Pekalongan dapat diketahui dengan menggunakan indikator biologi melalui indeks keanekaragaman, indek keseragaman dan indeks dominasi. Indeks indikator biologis dapat digunakan untuk menilai tingkat kualitas perairan berdasarkan dominansi organisme mikrobiologis yang ada disana (Nangin dkk, 2015). Adapun tujuan dari penelitian ini adalah untuk mengetahui kualitas air sungai Meduri ditinjau dari aspek fisika (suhu, kecerahan, TSS dan kedalaman), aspek kimia (DO, $\mathrm{pH}, \mathrm{BOD}, \mathrm{Cr}^{6+}$, Minyak dan Fenol) dan aspek biologi (plankton).

\section{METODE PENELITIAN}

Waktu dan tempat

Penelitian ini dilakukan di sungai meduri Kecamatan Tirto, Kabupaten Pekalongan Jawa Tengah (Tabel 1). Metode penelitian yang digunakan dalam penelitian ini adalah metode survey. Pengambilan sampel dilakukan pada 5 stasiun yaitu pada bagian upper stearm, middle stearm dan lower stearm sungai. Pengambilan sampel dilakukan pada 5 stasiun sebanyak 3 kali dengan interval waktu 2 minggu sekali.

\section{Bahan dan Pengambilan sampel}

Alat yang digunakan untuk pengambilan sampel plankton menggunakan plankton net dengan size 25. Selanjutnya, pengamatan dan identifikasi plankton menggunakan mikroskop Olympus CX22 dan

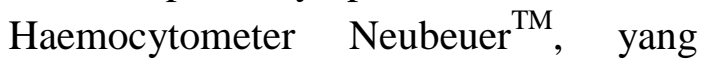
sebelumnya sampel telah diawetkan terlebih dahulu menggunakan Lugol iodine. Sedangkan untuk mengukur paraemeter kualitas air seperti oksigen terlarut menggunakan DO meter (YSI550I), suhu perairan dengan Termometer $\mathrm{Hg}$, kecerahan air dengan secchi disk dan keasaman air menggunakan $\mathrm{pH}$ meter $\left(\right.$ ECOTESTR $\left.^{\mathrm{TM}}\right)$.

\section{Parameter yang diamati}

Sampel plankton yang telah di identifikasi selanjutnya dihitung berdasarkan kelimpahan plankton, indeks keanekaragaman ( $\left.\mathrm{H}^{\prime}\right)$, indeks keseragaman (E), dan indeks dominansi plankton (D) berdasarkan rumus berikut (Sirait dkk, 2018):

\section{Kelimpahan Plankton}

$$
N=\frac{100(P x V)}{0,25 \cdot \pi \cdot W}
$$

Ket:

$\mathrm{N}=$ jumlah individu per liter

$\mathrm{P}=$ jumlah plankton tercacah

$\mathrm{V}=$ volume sampel plankton yang tersaring $(\mathrm{ml})$

$\mathrm{W}=$ volume sampel plankton yang disaring (liter) 
Indeks Keanekaragaman (H')

$$
\mathbf{H}^{\prime}=-\sum \text { pi ln pi }
$$

Ket:

$\mathrm{H}^{\prime}=$ Indeks Keanekaragam

$\mathrm{S}=$ Banyaknya jenis

$\mathrm{Pi}=\mathrm{n}_{\mathrm{i}}$ dibagi $\mathrm{n}$

$\mathrm{n}_{\mathrm{i}}=$ Jumlah individu ke- $\mathrm{n}$

$\mathrm{n}=$ Jumlah total individu

Indeks Keseragaman $(E)$

$$
E=\frac{H^{\prime}}{H m a k s}
$$

Ket:

$\mathrm{E}=$ Indeks Keseragaman

H' = Indeks Keanekaragaman

$\mathrm{H}_{\text {maks }}=$ In $\mathrm{s}$ (jumlah genus)

Indeks Dominansi $(D)$

Ket:

$$
D=\sum[\mathbf{n i} / \mathbf{N}]^{2}
$$

$\mathrm{D}=$ Indeks dominansi

ni $=$ Jumlah individu ke-i

$\mathrm{N}=$ Jumlah total individu.

\section{HASIL DAN PEMBAHASAN}

\section{Gambaran Umum Lokasi Penelitian}

Sungai Meduri terletak di kecamatan tirto. Sungai Meduri memiliki panjang $\pm 8 \mathrm{~km}$. Disekitar sungai Meduri terdapat beberapa industri batik dan pemukiman warga. Sebagian besar warga disekitar sungai Meduri bekerja sebagai pengrajin batik, tenaga buruh batik, pedagang, nelayan serta petambak.

\section{Parameter Kualitas Air}

Berdasarkan hasil pengukuran parameter kualitas perairan sungai Meduri yang diperoleh dari 5 stasiun masih dalam kisaran optimum. Dari hasil pengukuran suhu di perairan Sungai Meduri masih dalam batas normal pada tiap-tiap stasiun yaitu $25,67-29,67{ }^{0} \mathrm{C}$ hal ini sesuai dengan Hutabarat dan Evans, (2006) bahwa suhu air optimum rata-rata berkisar antara $24-32{ }^{0} \mathrm{C}$ pada kisaran tersebut plankton masih dapat tumbuh dan berkembang. Nilai suhu akan mempengaruhi tingkat produktifitas perairan secara diurnal (Ariadi dkk, 2020).

Kandungan kadar oksigen terlarut (Dissolved Oxygen/DO) terendah pada stasiun 3 dan 4 yaitu 2,37 dan 2,4 dikarenakan kondisi pada stasiun tersebut keruh sebab terdapat banyak beban masukan dari limbah batik dan limbah rumah tangga. Oksigen terlarut akan berfluktuasi secara dinamis sepanjang waktu mengikuti trend fluktuasi suhu (Ariadi dkk, 2019). Bahan bahan aktifitas domestik merupakan salah satu penyebab penurunan mutu air sungai (Aji dan Jailani, 2020).

Tabel 1. Posisi koordinat lokasi pengambilan sampel di perairan sungai meduri

\begin{tabular}{cccc}
\hline \multirow{2}{*}{ Stasiun } & \multicolumn{2}{c}{ Posisi Koordinat } & \\
\cline { 2 - 3 } & Lintang Selatan & Bujur Timur & Lokasi \\
\hline 1 & $06^{0} 96^{\prime}$ & $109^{0} 63^{\prime}$ & Anak Sungai Ngaliyan \\
3 & $06^{0} 90^{\prime}$ & $109^{0} 63^{\prime}$ & Cabang Sungai \\
4 & $06^{0} 89^{\prime}$ & $109^{\circ} 64^{\prime}$ & Area limbah batik \\
5 & $06^{0} 88^{\prime}$ & $109^{\circ} 64^{\prime}$ & Perairan limbah industri \\
\hline & $06^{0} 86^{\prime}$ & $109^{0} 65^{\prime}$ & Muara Sungai Meduri \\
\hline
\end{tabular}

Perairan yang telah terkandung bahan pencemar memiliki kandungan oksigen yang sangat rendah, makin banyak bahan bungan organik maka kandungan oksigen dalam air semakin sedikit (Wardhana, 2004). Kandungan 
Biological Oxygen Demand (BOD) di perairan Sungai Meduri memiliki nilai yang melebihi baku mutu air kelas III. Berdasarkan PP RI No. 82 Tahun 2001 tentang Pengelolaan Kualitas dan Pengendalian Pencemaran Air, Baku mutu air kelas III untuk parameter BOD adalah $3 \mathrm{mg} / \mathrm{l}$. Nilai $\mathrm{Cr}^{+}$dan Minyak masih berada dibawah baku mutu air kelas III yaitu $0,05 \mathrm{mg} / \mathrm{l}$ dan $1000 \mathrm{mg} / \mathrm{l}$. Sedangkan nilai fenol paling tinggi terdapat pada stasiun 3 dan 4 yaitu $0,11 \mathrm{mg} / \mathrm{l}$ dan $0,07 \mathrm{mg} / \mathrm{l}$, baku mutu nilai fenol adalah $1 \mathrm{mg} / \mathrm{l}$. Kandungan parameter kimia fisika dan air, secara terkait nantinya akan sangat menentukan pola dinamika ekosistem lingkungan perairan itu sendiri (Ariadi dkk, 2021).

Tabel 2. Hasil Pengukuran Parameter Kualitas Perairan Sungai Meduri

\begin{tabular}{lccccc}
\hline \multirow{1}{*}{ Parameter } & Stasiun 1 & Stasiun 2 & Stasiun 3 & Stasiun 4 & Stasiun 5 \\
\cline { 2 - 5 } & Rerata \pm SD & Rerata \pm SD & Rerata \pm SD & Rerata \pm SD & Rerata \pm SD \\
Suhu air $\left({ }^{0} \mathrm{C}\right)$ & $25,67 \pm 1,15$ & $26,33 \pm 0,58$ & $28 \pm 0$ & $28,67 \pm 2,08$ & $29,67 \pm 1,15$ \\
Kecerahan $(\mathrm{cm})$ & $27,33 \pm 27,33$ & $15,67 \pm 15,67$ & $5 \pm 5$ & $15 \pm 15$ & $21 \pm 21$ \\
TSS $(\mathrm{mg} / \mathrm{l})$ & $5,67 \pm 3,51$ & $28 \pm 27,78$ & $38 \pm 28,79$ & $11,67 \pm 9,61$ & $16,67 \pm 19,34$ \\
Kedalaman $(\mathrm{cm})$ & $146 \pm 1,73$ & $48,33 \pm 4,73$ & $197,67 \pm 1,53$ & $266,33 \pm 3,06$ & $388,33 \pm 1,53$ \\
DO $(\mathrm{mg} / \mathrm{l})$ & $4,3 \pm 1,01$ & $3,77 \pm 0,76$ & $2,37 \pm 0,4$ & $2,4 \pm 0,78$ & $3,33 \pm 0,98$ \\
pH & $6,33 \pm 0,58$ & $6 \pm 0,5$ & $5,83 \pm 0,29$ & $7,2 \pm 0,35$ & $6,3 \pm 0,52$ \\
BOD $(\mathrm{mg} / \mathrm{l})$ & $7,17 \pm 2,08$ & $6,38 \pm 1,15$ & $9,5 \pm 1,73$ & $8,67 \pm 2,08$ & $7,5 \pm 0,87$ \\
Cr ${ }^{6+}(\mathrm{mg} / \mathrm{l})$ & $0,003 \pm 0$ & $0,003 \pm 0$ & $0,003 \pm 0$ & $0,003 \pm 0$ & $0,003 \pm 0$ \\
Minyak $(\mathrm{mg} / \mathrm{l})$ & $4,09 \pm 3,91$ & $33,67 \pm 35,86$ & $4,87 \pm 4,41$ & $2,71 \pm 2,39$ & $5,25 \pm 4,58$ \\
Fenol $(\mathrm{mg} / \mathrm{l})$ & $0,05 \pm 0,05$ & $0,04 \pm 0,04$ & $0,11 \pm 0,02$ & $0,07 \pm 0,015$ & $0,15 \pm 0,24$ \\
\hline
\end{tabular}

Keterangan : SD : Standar Deviasi

\section{Indeks Plankton}

Indeks plankton yang diamati berupa uji kelimpahan jumlah plankton, indeks keanekaragaman (H'), indeks keseragaman (E), dan indeks dominansi (D). Berdasarkan indeks tersebut struktur plankton di perairan sungai meduri (Tabel 3 dan 4). Komunitas
Plankton di perairan sungai meduri didominansi oleh kelas

Bacillariophyceaea, Chyanophyceae, Chlorophyceae, Rotaria serta Entomostraca, dan terdapat 17 genera. Kelas Bacillariophyceaea merupakan kelas yang relatif sangat dominan di perairan sungai meduri (Tabel 4).

Tabel 3. Kelimpahan Plankton di Perairan Sungai Meduri

\begin{tabular}{cccc}
\hline Stasiun & \multicolumn{3}{c}{ Kelimpahan Plankton (ind/L) } \\
\cline { 2 - 4 } $\mathbf{1}$ & Lower Stearm & Middle Stearm & Upper Stearm \\
$\mathbf{2}$ & 2123 & 1104 & 5393 \\
$\mathbf{3}$ & 1358 & 1273 & 3439 \\
$\mathbf{4}$ & 1868 & 1783 & 2505 \\
$\mathbf{5}$ & 1316 & 1868 & 2420 \\
\hline
\end{tabular}

Bacillariophyceaea merupakan penyusun terbesar komunitas plankton dalam perairan Sungai Meduri. Kelimpahan stasiun1 berkisar antara
1104-5393 ind/l, stasiun 2 berkisar antara 1273-3439 ind/L, stasiun 3 berkisar antara 1783-2505 ind/l, stasiun 4 berkisar antara 1316-2420 ind/L, stasiun 5 bekisar antara 1614-2420 
individu/liter. Tingginya kelimpahan plankton Bacillariophyceaea disebabkan oleh tingginya beban nutrien dari limbah yang ada di sungai (Inayati dan Farid, 2020). Karena beban nutrien pada sungai yang berasal dari limpasan limbah sangat berpotensi untuk merubah rasio konsentrasi unsur $\mathrm{N}$ dan $\mathrm{P}$ di perairan (Ariadi dkk, 2021).

Tabel 4. Struktur Komunitas di Perairan Sungai Meduri

\begin{tabular}{cccccccccc}
\hline & \multicolumn{3}{c}{ Indeks Keanekaragaman } & \multicolumn{3}{c}{ Indeks Keseragaman } & \multicolumn{3}{c}{ Indeks Dominasi } \\
\cline { 2 - 10 } Stasiun & $\mathbf{1}$ & $\mathbf{2}$ & $\mathbf{3}$ & $\mathbf{1}$ & $\mathbf{2}$ & $\mathbf{3}$ & $\mathbf{1}$ & $\mathbf{2}$ & $\mathbf{3}$ \\
\hline 1 & 1,501 & 1,628 & 1,361 & 0,838 & 0,908 & 0,760 & 0,226 & 0,227 & 0,326 \\
2 & 1,723 & 1,574 & 1,723 & 0,828 & 0,978 & 0,829 & 0,232 & 0,022 & 0,221 \\
3 & 1,425 & 1,393 & 1,011 & 0,685 & 0,777 & 0,564 & 0,682 & 0,595 & 0,514 \\
4 & 1,465 & 1,49 & 1,191 & 0,753 & 0,831 & 0,740 & 0,297 & 0,307 & 1,000 \\
5 & 1,885 & 1,593 & 1,098 & 0,969 & 0,766 & 0,564 & 0,162 & 0,605 & 0,466 \\
\hline
\end{tabular}

Ket: 1: Lower stearm, 2: Middle stearm, 3: Upper stearm

Indeks Keanekaragaman (H') terendah pada stasiun 3 yaitu 1,0111,425 , bila nilai indeks keanekaragamn berkisar antara 1-1,5 menandakan perairan dalam kondisi tercemar sedang sampai berat (Anggoro, 1988). Kondisi tersebut ditandai dengan munculnya jenis plankton sebagi indikator perairan tercemar seperti Nitzschia, Navicula dan Oscilatoria. Nilai Indeks keseragaman (E') berkisar antara 0,564-0,978. Indeks keseragaman (E') paling rendah pada stasiun 3 berkisar antara 0,564-0,777 bila nilai E berkisar antara 1-6 berarti pemerataan antara genus relatif seragam atau jumlah individu masing-masing genera relatif sama. Tingkat keanekaragaman plankton tidak bisa lepas dari faktor kelimpahan unsur hara pada ekosistem lingkungan hidupnya (Ariadi dkk, 2021). Nilai Indeks Dominasi (D) berkisar antara 0,022-1, Nilai indeks Dominasi (D) $<0,5$ berarti tidak ada jenis yang mendominasi, tetapi pada stasiun 4 nilai indeks dominasi 1, berarti ada jenis yang mendominasi. Tingkat dominansi jenis plankton sangat erat dipengaruhi oleh faktor produktifitas perairan serta dinamika kualitas air yang ada, karena secara biologis plankton merupakan mikroorganisme yang bersifat kosmopolit (Ariadi, 2019; Wafi dkk, 2021).

\section{KESIMPULAN}

Kualitas air sungai Meduri masih sesuai standar baku mutu air kelas III, kecuali DO berkisar antara 2,37 - 4,3 $\mathrm{mg} / \mathrm{L}$ dan BOD berkisar antara 6,38 9,5 $\mathrm{mg} / \mathrm{L}$. Kelimpahan plankton berkisar antara 1104 - 5393, Indeks keanekaragaman (H') berkisar antara 1,011 - 1,885, yang berarti perairan di sungai meduri dalam kondisi tercemar sedang sampai berat.

\section{DAFTAR PUSTAKA}

Aji, M. T., \& Jailani, A. Q. (2020). Studi Kualitas Air Tanah Kota Magelang Akibat Dampak Limbah Domestik dan Industri Study of Groundwater Quality in Magelang City Due to the Impact of Domestic and Industrial Waste. Journal of Aquaculture Science, 5(2), 120-128. 
Anggoro S. 1983. Tropic-Saprobic Analysis : Metode Evaluasi Kelayakan Lokasi Budidaya Biota Akuatik [tesis]. Bogor (ID): Institut Pertanian Bogor.

Anggoro S. 1988. Analisis Tropik Saprobik untuk Menilai Kelayakan Lokasi Budidaya Laut. Perguruan Tinggi se Jawa Tengah [disertasi]. Semarang (ID): LPWP Universitas Diponegaro.

Ariadi H. 2019. Konsep Pengelolaan Budidaya Udang Vannamei (Litopenaeus vannamei) Pola Intensif Berdasarkan Tingkat Konsumsi Oksigen Terlarut [tesis]. Malang (ID): Universitas Brawijaya.

Ariadi H, Fadjar M, Mahmudi M, Suprianta. 2019. The relationships between water quality parameters and the growth rate of white shrimp (Litopenaeus vannamei) in intensive ponds. AACL Bioflux 12(6): 21032116.

Ariadi H, Mahmudi M, Fadjar M. 2019. Correlation between Density of Vibrio Bacteria with Oscillatoria sp. Abundance on Intensive Litopenaeus vannamei Shrimp Ponds. Research Journal of Life Science 6(2): 114129.

Ariadi H, Wafi A, Supriatna. 2020. Hubungan Kualitas Air Dengan Nilai FCR Pada Budidaya Intensif Udang Vanname (Litopenaeus vannamei). Samakia: Jurnal Ilmu Perikanan 11(1): 44-50.

Ariadi H, Wafi A, Musa M, Supriatna. 2021. Keterkaitan Hubungan Parameter Kualitas Air Pada Budidaya Intensif Udang Putih (Litopenaeus vannamei). Samakia: Jurnal Ilmu Perikanan 12(1): 18-27.
Ariadi H, Wafi A, Supriatna, Musa M. 2021. Tingkat Difusi Oksigen Selama Periode Blind Feeding Budidaya Intensif Udang Vaname (Litopenaeus vannamei). Rekayasa 14(2): 152-158.

Ariadi H, Wafi A, Madusari B.D. 2021. Dinamika Oksigen Terlarut (Studi Kasus Pada Budidaya Udang). Penerbit ADAB, Indramayu.

Astirin O.P, Ahmad D.S, dan Marti H. 2002. Keragaman Plankton sebagai Indikator Kualitas Sungai di Surakarta. Biodiversitas 3(2): 236241.

Hutabarat S dan Evans S.M. 2006. Pengantar Oseanografi. Penerbit Universitas Indonesia, Jakarta.

Inayati W, dan Farid A. 2020. Analisis Beban Masuk Nutrien Terhadap Kelimpahan Klorofil-A Saat Pagi Hari Di Sungai Bancaran Kabupaten Bangkalan. Juvenil 1(3): 406-416.

Sirait M, Rahmatia F, Pattulloh. 2018. Komparasi Indeks Keanekaragaman dan Indeks Dominansi Fitoplankton Di Sungai Ciliwung Jakarta. Jurnal Kelautan 11(1): 75-79.

Wafi A, Ariadi H, Muqsith A, Mahmudi M, Fadjar M. 2021. Oxygen Consumption of Litopenaeus vannamei in Intensive Ponds Based on the Dynamic Modeling System. Journal of Aquaculture and Fish Health 10(1): 17-24.

Wardhana W. A. 2004. Dampak Pencemaran Lingkungan. Penerbit Andi, Yogyakarta. 